\title{
Strategi Pengembangan Usaha Garam Dengan Metode Rumah Garam Prisma Di Desa Sedayulawas Kecamatan Brondong Kabupaten Lamongan
}

\author{
Salt Business Development Strategy Using Salt Prisma House Method In \\ Sedayulawas Village Brondong Lamongan
}

\author{
Muntalim $^{1 *}$, Ika Purnamasari ${ }^{1}$, Endah Sih Prihatinii ${ }^{1}$, Nadiyah Khalifatun Rosyidah ${ }^{1}$ \\ ${ }^{1}$ Prodi Agrobisnis Perikanan Fakultas Perikanan Universitas Islam Lamongan \\ Jl. Veteran, No. 53 A Lamongan \\ *Corresponding Author : bapak.talim151@unisla.ac.id
}

\begin{abstract}
ABSTRAK
Desa Sedayulawas merupakan salah satu sentra produksi garam di Lamongan, dimana kuantitas produksi tergantung iklim, jika musim hujan tiba produksi garam akan terhenti hingga musim kemarau, sehingga di perlukan suatu inovasi Rumah garam prisma yang mana merupakan inovasi yang sangat tepat dalam memproduksi garam rakyat menggunakan plastik geomembran. Tujuan dari penelitian ini untuk mengetahui cara pembuatan rumah garam prisma, analisis finansial usaha dan menganalisis strategi yang tepat dalam mengembangkan usaha rumah garam prisma. Metode penelitian yang digunakan yaitu analisis SWOT. Teknik sampling yang digunakan adalah purposive sampling yaitu teknik pengambilan sampel sumber data dengan pertimbangan tertentu berdasarkan tujuannya. Berdasarkan diagram SWOT, IFAS, EFAS hasil penelitian menujukan bahwa, Faktor Internal dan Faktor Eksternal Usaha Rumah Garam Prisma desa Sedayulawas Kecamatan Brondong Kabupaten Lamongan berada pada kuadran I yaitu menggunakan Strategi Agresif dimana perusahaan memiliki kekuatan dan peluang besar.
\end{abstract}

Kata kunci : Garam, Lamongan, Rumah Garam Prisma, Strategi Agresif, SWOT

\begin{abstract}
Sedayulawas village is one of the salt production centers in Lamongan, where the quantity of production depends on the climate. If the rainy season comes, salt production will stop until the dry season, so an innovation is needed in the Prism salt house which is a very appropriate innovation in producing people's salt using plastic geomembrane. The purpose of this study is to find out how to make a prism salt house, financial analysis of the business and analyze the right strategy in developing a prism salt house business. The research method used is the SWOT analysis. The sampling technique used was purposive sampling, which is the technique of sampling data sources with certain considerations based on the objectives. Based on the SWOT diagram, IFAS, EFAS research results show that, Internal Factors and External Factors of Prisma Salt House Business in Sedayulawas village, Brondong Subdistrict, Lamongan Regency is in quadrant I, which uses Aggressive Strategy where the company has great strengths and opportunities.
\end{abstract}

Keywords : Salt, Lamongan, Pram Salt House, Aggressive Strategy, SWOT

\section{PENDAHULUAN}

Indonesia merupakan negara kepulauan terbesar di dunia yang memiliki pulau mencapai 17.508 pulau dan wilayah seluas $7.700 .000 \mathrm{~km} 2$. Indonesia memiliki garis pantai terpanjang ke-4 di dunia yaitu $95.181 \mathrm{~km}$. Dari kelebihan yang di miliki negara Indonesia sebagai negara maritim tentu terdapat berbagai potensi kelautan dan perikanan yang melimpah, namun potensi tersebut masih belum digali secara optimal. Sektor kelautan dan perikanan yang banyak digali salah satunya adalah garam. Garam merupakan komoditas strategis, karena selain 
merupakan kebutuhan pokok yang di konsumsi manusia lebih kurang $4 \mathrm{~kg}$ per tahun juga di gunakan sebagai bahan baku industri (Kementrian Kelautan dan Perikanan, 2011 dalam Widiarto 2013).

Dalam memenuhi kebutuhan pokok garam lokal, produksi garam negeri belum mampu memenuhi kebutuhannya, sehingga masih bergantung pada garam luar negeri. Dengan potensi dan daya dukung alam kelautan tersebut seharusnya Indonesia mampu memproduksi dan memenuhi kebutuan garam sendiri dengan melihat Luas lahan garam produktif di Indonesia mencapai 20.089 Ha. (Kementrian Kelautan dan Perikanan, 2013)

Salah satu kabupaten penghasil garam terbesar di Jawa Timur adalah Kabupaten Lamongan. Salah satu kendala petani garam adalah cuaca yang berubah misalnya saja saat musim hujan atau kemarau basah, bisa dipastikan hasil garam akan menurun. Namun, hal ini tak berlaku bagi beberapa kelompok petani garam di Lamongan. Inovasi yang dibuat bisa menjadikan bertani garam tak lagi harus bergantung pada musim. Rumah garam prisma, demikian rumah garam inovasi baru karya petani Lamongan, Samian Arifin, warga Desa Sedayulawas, Kecamatan Brondong. Dengan memberi atap plastik, kini tambak garamnya tak perlu bergantung pada musim sehingga bisa terus berproduksi garam. Dari banyak petani garam di Desa Sedayulawas Kecamatan Brondong, hanya beberapa kelompok petani garam yang menggunakan metode rumah garam prisma. Kebanyakan kelompok petani lain masih menggunakan metode konvensional. Oleh karena itu sangat butuh dikembangkan inovasi rumah garam prisma ini agar para petani garam tak lagi bergantung pada musim sehingga meningkatkan hasil garam dan dapat menyukupi kebutuhan garam nasional.

Pengembangkan inovasi rumah garam prisma tentu diperlukan pengetahuan tentang bagaiman cara pembuatan rumah garam prisma yang baik dan benar sehingga dapat menghasilkan produksi yang maksimal, selain itu untuk dapat mempertahankan suatu usaha juga sangat diperlukan strategi-strategi pengembangan usaha dan diperlukan juga perhitungan finansial agar diketahui tingkat keuntungan usaha tersebut.

Berdasarkan uraian latar belakang diatas maka peneliti terarik untuk melakukan penelitian tentang bagiamana cara pembuatan rumah garam prisma, analisis finansial usaha dan menganalisis strategi yang tepat dalam mengembangkan usaha rumah garam prisma tersebut.

\section{METODE PENLITIAN}

\section{Jenis Data}

Dalam suatu penelitian harus disebutkan dari mana data diperoleh sebagaimana yang dinyatakan oleh (Arikunto 2002). Data adalah sekumpulan informasi, fakta-fakta, atau simbol-simbol yang menerangkan tentang keadaan objek penelitian. Sedangkan data yang sudah didapet akan dibagi menjadi dua macam yaitu : Data primer adalah data dimana diperoleh secara langsung dari objek penelitian (Sumarsono, 2004). Dan data skunder merupakan sumber data yang diperoleh peneliti secara tidak langsung melalui media perantara (Indriantoro dan Supomo, 1999).

Dalam penelitian ini data primer diperoleh dari hasil wawancara dengan petani garam prisma, observasi dan kuisioner. Sedangkan data sekunder diperoleh dari instansi terkait, jurnal dan buku referensi.

\section{Metode Pengambilan Sampel}

Dalam penelitian ini teknik sampling yang digunakan yaitu nonprobility sampling denga teknik snowball sampling Menurut Sukandarrudin dan haryanto (2007) bahwa: "Snowball sampling adalah teknik pengambilan sampel Seperti bola salju, dimana oran pertama yang dipakai sebagai anggota sampel ditentukan terlebih dahulu, kemudian orang pertama diminta menunjukan dua orang yang akan di pakai sebagai sampel kedua dan ketiga demikian seterusnya, proses yang sama dilakukan sampai jumlah sampel yang diinginkan terpenuhi”. Jumlah sampel yang diambil dalam penelitian ini adalah 3 petani garam rumah prisma di desa Sedayulawas Kecamatan Brondong Kabupaten Lamongan

\section{Teknik Pengumpulan Data}

Dalam pengumpulan data penelitan menggunakan langkah-langkah sebagai berikut:

Interview 
Interview dikenal pula sebagai wawancara, yaitu suatu proses tanya jawab secara lisan antara interviewer (orang yang menginterview atau mewawancarai) dengan interviewee (orang yang di interview atau narasumber).

\section{Obeservasi}

Observasi adalah melakukan pengamatan dan pencatatan suatu obyek, secara sistematik fenomena yang diselidiki. Observasi dapat dilakukan oleh orang yang tepat, menguasai bidang ilmu dan mempunyai tingkat "kepekaan indera" tinggi.

\section{Kuesioner}

Kuesioner atau angket adalah teknik pengumpulan data dengan mengirim suatu daftar pertanyaan kepada responden untuk diisi.

\section{Analisi Data}

Analisis data adalah upaya yang dilakukan dengan jalan bekerja dengan data, mengorganisasikannya, mencari dan menemukan pola, menemukan apa yang penting dan apa yang dipelajari, dan memutuskan apa yang dapat diceritakan kepada orang lain (Lexy, 2005) .

Data yang diperoleh, dituangkan dalam suatu rancangan konsep yang kemudian dijadikan dasar utama dalam memberikan analisis. Dalam penelitian ini yang digunakan dalam menganalisa data yang sudah diperoleh adalah dengan cara deskriptif, yaitu penelitian yang dilakukan dengan menggambarkan data yang diperoleh dengan kata-kata atau kalimat yang dipisahkan untuk memperoleh kesimpulan. Yang bermaksud mengetahui keadaan sesuatu yaitu mengenai apa dan bagaimana, berapa banyak, sejauh mana, dan sebagainya.

Dalam penelitian ini, untuk menganalisis data peneliti menggunakan beberapa tahapan teknik analisis data yang dimulai dari pengumpulan data yang peneliti gali melalui wawancara observasi dan dokumentasi. Pada tahap kedua peneliti mengolah data menggunakan metode SWOT, Pada tahap ketiga yaitu penyajian data yang telah melalui proses pengolahan data (reduksi data) untuk disajikan dengan fokus penelitian. Tahap terakhir yaitu peneliti menarik kesimpulan dari data-data yang telah disajikan atau mencari poin-poin penting agar mudah dipahami.

\section{HASIL DAN PEMBAHASAN}

\section{Cara Pembuatan Rumah Garam Prisma}

Adapun beberapa yang perlu disiapkan untuk membuat rumah garam prisma yaitu bambu, geomembran, dan plastik uv yang transparant. Pertama yang harus di siapkan adalah penampungan air sungai atau air laut laut (bangker air muda), selanjutnya menyiapkan ulir, ulir ini berguna sebagai aliran air muda menuju bangker air tua, dan yang selanjutnya menyiapkan bambu untuk membuat kerangka rumah garam prisma yang atapnya harus berbentuk prisma karena bangunan ini di bentuk di tengah tanah lapang sehingga bangunan rumah garam prisma harus tahan angin, dan menurut bapak arifin setelah melakukan uji coba bentuk prisma merupakan bentuk yang tahan angin selain itu panas nya fokus dan irit bahan baku, pada tahap selanjutnya pemasangan lantai meja garam menggunakan geomembran, setelah itu penutupan atap menggunakan uv transparant.

Di dalam satu unit rumah garam prisma terdapat dua tingkat meja penampungan air yaitu penampungan air pada bagaian bawah di gunakan untuk menyimpan air tua dan pada bagian atas digunakan untuk meja pembuatan garam.

Pembuatan garam pada teknik rumah garam prisma berawal pada penampuangan air laut atau air sungai setelah itu di pompa dan di alirkan ke ulir sehingga air terus mengalir, cara ini bermaksud untuk mendapatkan bahan baku yang berkualitas baik, menurut Bapak Arifin air yang di biarkan saja kualitasnya berbeda dengan air yang di alirkan keulir yang hasilnya akan lebih bagus. Setelah mengalir pada ulir yang panjangnya sekitar 4500 meter, air tersebut di simpan dalam rumah garam prisma sebagai air tua bahan baku garam atau langsung di proses menjadi garam.

Produktivitas rumah garam prisma lebih unggul dari teknik pembuatan garam biasa, dimana produktivitas bisa naik 3-4 kali lipat. Bapak Arifin dan responden lainnya menyatakan bahwa pada musim normal rumah garam prisma dapat memproduksi $100-125$ ton per hektarnya dalam satu kali produksi atau bahkan lebih jika mempunyai penyimpanan air 
tua yang banyak maka per tahunya bisa menghasilkan 400 ton garam per satu tahun dengan luas satu hektar.

Garam yang di produksi biasanya langsung di jual ke koprasi garam Lamongan guna di distribusikan ke pabrik - pabrik garam, akan tetapi terkadang Bapak Arifin menjual garam keluar jawa karna adanya permintaan dari konsumen di luar jawa yang tidak mendapatkan stok garam di daerahnya pada musim hujan. Sistem penjualan garam pada usaha ini adalah sesuai permintaan konsumen.

\section{Analisa Kelayakan Usaha Rumah Garam Prisma}

Analisis Kelayakan Usaha adalah untuk mengetahui dan mengukur layak dan tidakanya suatu bisnis atau usaha untuk dijalankan. Berikut adalah analisa kelayakan usaha garam dengan metode rumah garam prisma :

\section{Biaya Investasi}

Tabel.1 Biaya Investasi

\begin{tabular}{ll}
\hline \multicolumn{1}{c}{ Uraian } & \multicolumn{1}{c}{ Jumlah } \\
\hline Peralatan Produksi & Rp. 284.975.000 \\
Gudang Garam & Rp. 37.000.000 \\
Jumlah biaya investasi & Rp. 321.975.000 \\
\hline
\end{tabular}

Sumber : Data Primer (2019)

\section{Biaya Oprasional selama 1 tahun}

Biaya oprasional selama satu tahun yaitu biaya yang di gunakan untuk memproduksi selama satu tahun, adapaun biaya yang digunakan adalah biaya tetap dan biaya tidak tetap.

Biaya tetap yaitu baiaya yang nilainya secra relatif tidak di pengaruhi oleh besarnya jumlah produksi (output ) sedangkan biaya tidak tetap adalah biaya yang nilainya pengaruhi oleh banyaknya output.

Tabel.2 Biaya Tetap

\begin{tabular}{ll}
\hline \multicolumn{1}{c}{ Uraian } & \multicolumn{1}{c}{ Jumlah } \\
\hline Biaya Penyusutan & Rp. 32.197 .500 \\
Biaya Tenaga Kerja & Rp. 54.000.000 \\
Biaya Sewa Lahan & Rp. 25.000.000 \\
\hline Jumlah Biaya Tetap & Rp. 111.797.500 \\
\hline Sumber : Data Primer (2019)
\end{tabular}

Biaya Total adalah Biaya Tetap ditambah dengan Biaya Produksi yaitu sebesar Rp 119.779.500.

Tabel.3 Biaya Tidak Tetap

\begin{tabular}{cll}
\hline No & \multicolumn{1}{c}{ Uraian } & \multicolumn{1}{c}{ Jumlah } \\
\hline 1 & BBM & Rp. 5.000 .000 \\
2 & Karung & Rp. 3.500 .000 \\
3 & Tali & Rp. 100.000 \\
\hline \multicolumn{2}{l}{ Jumlah biaya produksi } & Rp. 8.600 .000 \\
\hline \multicolumn{2}{l}{ Sumber : Data Primer (2019) }
\end{tabular}

Modal Usaha adalah Biaya Investasi ditambah dengan Biaya Total yaitu sebesar Rp 441.754.500

\section{Pendapatan}

Pendapatan adalah jumlah uang yang di terima oleh perusahaan dari aktifitasnya. Pada tabel di bawah ditunjukan pendapatan pengolahan garam dengan metode rumah garam prisma selama 1 tahun.

Tabel. 4 Pendapatan

\begin{tabular}{ccc}
\hline Produksi (ton) & Harga/kg & Jumlah \\
\hline 125 & 2000 & 250.000 .000 \\
\hline Sumber : Data Primer $(2019)$ &
\end{tabular}

4. $\quad$ Analisa Laba Rugi

Analisis laba rugi atau biasa di sebut laporan laba rugi adalah salah satu komponen dari laporan keuangan yang melaporkan pendapatan atau keuntungan perusahaan pada jangka waktu tertentu. Berikut ini adalah analisa laba rugi usaha garam dengan metode mumah garam prisma di Desa Sedayulawas Kecamatan Brondong Kabupatrn Lamongan.

Keuntungan $=$ Penerimaan - Biaya total $=$ Rp. $250.000 .000-$ Rp. 119.779 .500 $=$ Rp. 130.220 .500

\section{5.}

Return Cost Ratio (R/C)

Return Cost Ratio (R/C) di gunakan untuk melihat besarnya keuntungan relatif dari usah garam dengan metode rumah garam prisma di Desa Sedayulawas Kecamatan Brondong Kabupatrn Lamongan. Dalam satu tahun terhadap biaya yang di keluarkan. Usaha di katakan layak bila nila $\mathrm{R} / \mathrm{C}$ ratio lebih besar dari 1. Semakin tinggi nilai $\mathrm{R} / \mathrm{C}$ ratio, tingkat keuntungan usaha akan semakin tinggi.

$$
\mathrm{R} / \mathrm{C}=\frac{\text { Penerimaan }}{\text { biaya total }}=\frac{\mathrm{Rp} \cdot 250,000,000}{\mathrm{Rp} \cdot 119.779 .500}=2,0
$$


Berdasarkan hasil analisi R/C bahwa usaha pembuatan garam dengan metode rumah garam prisma layak di kembangkan dan menguntungkan karena nilai $\mathrm{R} / \mathrm{C}=2,0$ artinya bahwa setiap Rp. 1.000 biaya yang di keluarkan menghasilkan tambahan penerimaan sebesar Rp. 2.000

\section{Strategi Pengembangan Rumah Garam Prisma}

Sumber : Data Primer (2019)
Setelah faktor-faktor strategi internal dan eksternal suatu perusahaan diidentifikasii, suatu tabel IFAS dan EFAS disususn untuk merumuskan faktor-faktor strategi internal dan internal tersebut dalam kerangka kekuatan, kelebihan peluang dan ancaman. Dari hasil pengamatan dan wawancara atas kuisioner pada responden yang dipilih. Dari data diatas akan di buat matriks IFAS dan EFAS berikut gambaran matriks yang ada dapat dilihat pada Tabel 6 dan Tabel 7.

Tabel.6 Matriks Faktor Strategi Internal

\begin{tabular}{lccc}
\hline \multicolumn{1}{c}{ FAKTOR INTERNAL } & BOBOT & RATING & BOBOT x RATING \\
\hline KEKUATAN (STRENGHT) & & & \\
\hline Efesiensi Lahan & 0,123 & 3 & 0,37 \\
Produksi sepanjang musim & 0,135 & 3 & 0,40 \\
Keunggulan produk & 0,139 & 3 & 0,42 \\
Dapat memproduksi garam sesuai permintaan & 0,123 & 3 & 0,37 \\
Ketersedian bahan baku & 0,090 & 1 & 0,09 \\
\hline JUMLAH NILAI KEKUATAN & & & $\mathbf{1 , 6 5}$ \\
\hline KELEMAHAN (WEAKNESSES) & & & 0,12 \\
\hline Biaya investasi lebih tinggi & 0.060 & 2 & 0,16 \\
Waktu panen lebih lama & 0,080 & 2 & 0,1 \\
Investasi tidak tahan lama & 0,050 & 2 & 0,27 \\
Belum banyak dikembangkan di daerah sekitar & 0,110 & 4 & $\mathbf{1 , 0 9}$ \\
Kualitas SDM & 0,090 & 3 & $\mathbf{2 , 7 4}$ \\
\hline JUMLAH NILAI KELEMAHAN & & & $\mathbf{0 , 5 6}$ \\
\hline TOTAL IFAS & $\mathbf{1 , 0 0}$ & & \\
SELISIH IFAS & & & \\
\hline
\end{tabular}

Tabel.7 Matriks Faktor Strategi eksternal

\begin{tabular}{llccc}
\hline No & \multicolumn{1}{c}{ FAKTOR EKSTERNAL } & BOBOT & RATING & BOBOT x RATING \\
\hline A & PELUANG (OPPORTUNITIES) & & & \\
& & & & \\
1 & Mengembangkan usaha rumah garam & 0,131 & 3 & 0,39 \\
2 & prisma secara luas & 0,135 & 3 & 0,41 \\
3 & Produksi sesuai permintaan pasar & 0,107 & 2 & 0,21 \\
4 & Dutensi perluasan pasar & 0,100 & 2 & 0,2 \\
5 & Persaingan dari pemerintah & 0,107 & 2 & 0,21 \\
\hline & JUMLAH NILAI PELUANG serupa sangat rendah & & $\mathbf{1 , 4 2}$ \\
\hline
\end{tabular}




\begin{tabular}{llccc}
\hline B & ANCAMAN (THREATS) & & & \\
\hline 1 & Bencana alam & 0,100 & 3 & 0,3 \\
2 & Penetapan harga dari pemerintah tidak stabil & 0,084 & 4 & 0,34 \\
3 & Impor yang melebihi kuota & 0,060 & 2 & 0,12 \\
4 & Munculnya usaha sejenis & 0,086 & 2 & 0,17 \\
5 & fluktuasi permintaan konsumen akan garam & 0,100 & 3 & 0,3 \\
\hline & JUMLAH NILAI ANCAMAN & & $\mathbf{1 , 2 3}$ \\
\hline & TOTAL EFAS & $\mathbf{1 , 0 0}$ & & $\mathbf{2 , 6 5}$ \\
& & & $\mathbf{0 , 1 9}$ \\
\hline
\end{tabular}

Dari kedua tabel diatas bisa dijelaskan bahwa :

1. Jumlah dari skor pembobotan pada kekuatan yaitu 1,65 diatas dari peluang yaitu 1,42 sehingga dapat menciptakan strategi yang menggunakan kekuatan untuk memperoleh peluang. Kekuatan yang ada pada usaha rumah garam prisma harus di lakukan secara maksimal agar dapat memperoleh peluang yang ada.

2. Jumlah skor pembobotan pada kekuatan lebih besar dari ancaman yaitu kekuatan 1,65 sedangkan ancaman 1,23 sehingga dapat menciptakan strategi yang menggunakan kekuatan untuk mengatasi ancaman. Kekuatan Usaha rumah garam prisma harus lebih di maksimalkan lagi agaram dapat mengantisipasi ancaman yang ada.

3. Jumlah dari skor pembobotan pada kelemahan lebih rendah dari peluang yaitu kelemahan 1,09 sedangkan peluang 1,42 sehingga dapat meciptakan strategi pada peluang yang mampu meminimalkan kelemahan, peluang yang ada harus di manfaatkan semaksimal mungkin agar dapat menutupi kelemahan yang ada pada usaha rumah garam prisma.

4. Jumlah dari skor pembobotan pada kelemahan hampir sama dengan ancaman yaitu 1,09 dan 1,23 maka sehingga pengusaha harus lebih denfensif dalam usahanya untuk meminimalkan jumlah ancaman dan kelemahannya agar usahanya dapat berkembang,

Penjelasan dari tabel diatas dari tahap pengumpulan data, dapat di peroleh yang lebih spesifik dengan cara membuat "tahap analisis", dimana memasukan semua informasi kedalam model perumusan strategi. Model tersebut adalah Matriks SWOT sehingga dapat memunculkan beberapa kategori yakni strategi SO, strategi ST, strategi WO, strategi WT.

Tahap selanjutnya yaitu tahap terakhir "tahap pengambilan keputusan" tahap ini untuk menyusun beberapa startegi yang telah di gambarkan oleh Matriks SWOT seperti pada Tabel 8, sehingga staretegi yang mncul dapat menjadi acuan dalam memperbaiki strategi pengembangan usaha garam prisma di Desa Sedayulawas Kecamatan Brondong Kabupaten Lamongan, adapun yang di maksud adalah:

1. Strategi SO

Stategi SO dibuat dengan memanfaatkan secara maksimal kekuatan internal perusahaan untuk mendapatkan peluang yang maksimal. Alternatif strategi yang di rekomendasikan kepada perusahaan yaitu :

1. Meningkatkan produksi dan kualitas produk

Dengan meningkatkan produksi dan kualitas produk maka perusahaan memilik keunggulan dalam ketersediaan produk dan kualitas sehingga konsumen tidak perlu khawatir kehabisan produk ataupun kualitas produk.

2. Mengandalkan produksi sepanjang musim untuk menarik pelanggan.

Dengan produksi sepanjang musim maka pelanggan akan tetap mendapatkan garam dalam waktu atau musim garam langka.

2. Strategi WO

Strategi WO bertujuan untuk meminimalkan kelemahan internal perusahaan dengan memanfaatkan peluang yang ada. Berikut beberapa alternatif strategi yang di rekomendasikan kepada perusahaan yaitu 
1. memanfaatkan dukungan dari pemerintah dengan baik guna perusahaan dapat mengembangkan usaha rumah garam prisma

2. Memproduksi lebih banyak memperpuas pasar sehingga dapat menutupi biaya investasi yang lebih tinggi.

\section{Strategi ST}

Strategi ST adalah strategi yang menggunakan kekuatan perusahaan untukmenghindari $\mathrm{Tu}$ mengurangi pengaruh dari ancaman eksternal. Adapun beberapa alternatif strategi yang di rekomendasikan kepada perusahaan yaitu :

1. Meningkatkan kualitas usaha dan produk

Perusahaan harus lebih meningkatkan usahanya dan kualitas produknya agar permintaan konsumen stabil atau lebih meningkat

2. memproduksi produk secara setabil dengan kualitas baik
Perusahaan harus dapat memproduksi produk secara stabil dengan kualitas baik pada setiap musim agar kebutuhan garam di daerah sekitar maupun di luar daerah selalu terpenuhi sehingga memperkecil impor garam serta menambah konsumen.

\section{Strategi WT}

Strategi WT adalah strategi yang didasarkan pada kegiatan yang bersifat defensif dan berusaha meminimalkan kelemahan yang ada serta menghindari ancaman. Adapun beberapa alternatif strategi yang di rekomendasikan kepada perusahaan yaitu :

1. Memberi pelatihan khusus pada SDM tentang rumah garam prisma agar dapat di kembangkan dengan baik

2. Mengembangkan usaha rumah garam prisma agar kebutuhan garam dalam negri tercukupi sehingga memperkecil impor garam.

Tabel. 8 Matriks SWOT

\begin{tabular}{|c|c|c|}
\hline $\begin{array}{ll}\text { Faktor } \\
\text { Internal }\end{array}$ & \begin{tabular}{l}
$\quad$ Strength (S) \\
\multicolumn{1}{c}{ 1. Efesiensi lahan } \\
2. Produksi sepanjang musim \\
3.Keunggulan produk \\
4. Dapat memproduksi dengan \\
kualitas garam sesuai \\
permintaan \\
5.ketersedian bahan baku
\end{tabular} & $\begin{array}{l}\quad \text { Weakness }(\mathbf{W}) \\
\text { 1. Biaya investasi lebih tinggi } \\
\text { 2. Waktu panen lebih lama } \\
\text { 3. investasi tidak tahan lama } \\
\text { 4 . belum banyak di } \\
\text { kembangkan di daerah sekitar } \\
\text { 5. Kualitas SDM }\end{array}$ \\
\hline $\begin{array}{l}\qquad \text { Opportunity }(\mathbf{O}) \\
\text { 1.Mengembangkan usaha } \\
\text { rumah gram prisma secara } \\
\text { luas } \\
\text { 2. produksi sesuai } \\
\text { permintaan pasar } \\
\text { 3. Potensi perluasan pasar } \\
\text { 4.Dukungan dari pemerintah } \\
\text { 5.Persaingan dengan } \\
\text { produksi serupa sangat } \\
\text { rendah }\end{array}$ & $\begin{array}{l}\qquad \text { Strategi (SO) } \\
\text { 1. meningkatkan produksi dan } \\
\text { kualitas produk. } \\
\text { 2. Mengandalkan produksi } \\
\text { sepanjang musim agar } \\
\text { permintaan pelanggan slalu } \\
\text { terpenuhi. }\end{array}$ & $\begin{array}{l}\quad \text { Strategi (WO) } \\
\text { 1. memanfaatkan dukungan dari } \\
\text { pemerintah dengan baik guna } \\
\text { mengembangkan usaha rumah } \\
\text { garam prisma } \\
\text { 2. Memproduksi lebih banyak } \\
\text { sehingga dapat menutupi biaya } \\
\text { investasi yang lebih tinggi }\end{array}$ \\
\hline $\begin{array}{l}\quad \text { Treaths }(\mathbf{T}) \\
\text { 1.Bencana alam } \\
\text { 2.penetapan harga dari } \\
\text { pemerintah tidak stabil } \\
\text { 3.impor yang melebihi kuota } \\
\text { 4.munculnya usaha yang }\end{array}$ & \begin{tabular}{l}
\multicolumn{1}{c}{ Strategi (ST) } \\
1. meningkatkan kualitas usaha \\
dan produk agar permintaan \\
konsumen stabil atau lebih \\
meningkat \\
2. memproduksi produk secara
\end{tabular} & \begin{tabular}{l}
\multicolumn{1}{c}{ Strategi (WT) } \\
1. memberi pelatihan khusus \\
pada SDM tentang rumah garam \\
prisma agar dapat di \\
kembangkan dengan baik \\
2. Mengembangkan usaha
\end{tabular} \\
\hline
\end{tabular}




\begin{tabular}{|l|l|l|}
\hline sejenis & setabil dengan kualitas baik & rumah garam prisma agar \\
konsumen akan garam & pada setiap musim agar & kebutuhan garam dalam negri \\
& kebutuhan garam slalu terpenuhi & tercukupi \\
sehingga memperkecil impor & garam. & \\
& & \\
\hline
\end{tabular}

A

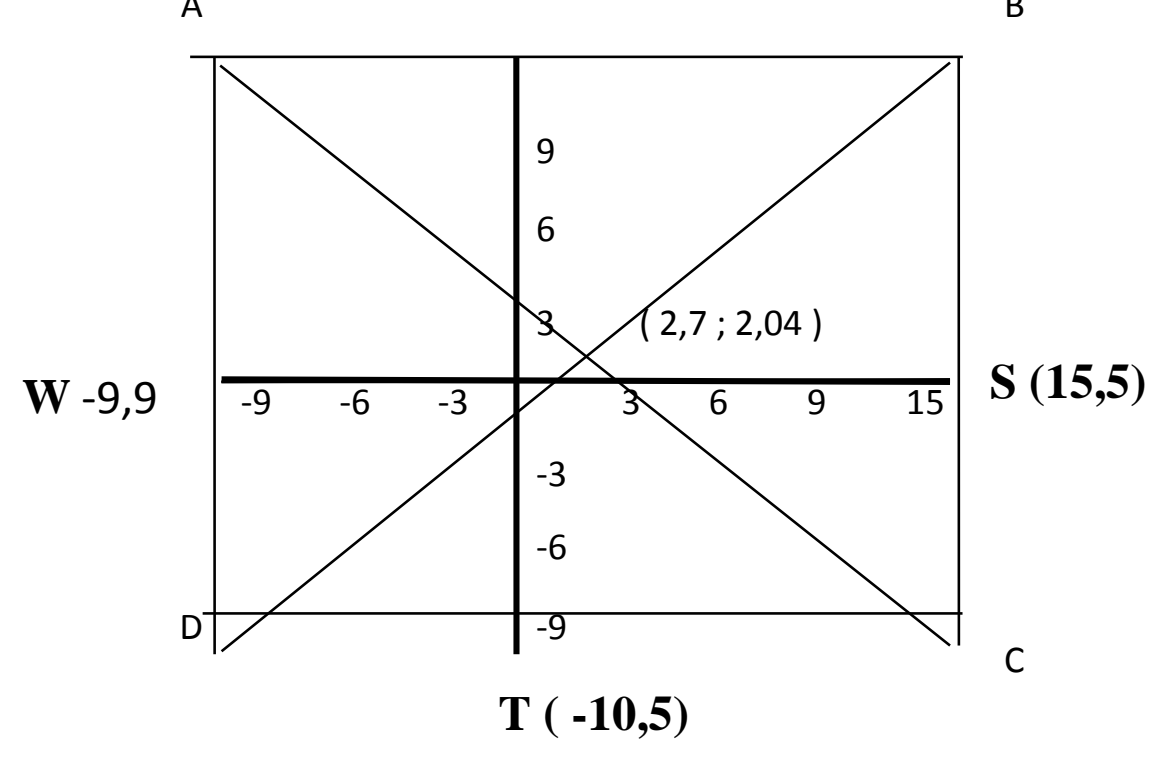

B

Gambar 1. Kuadran SWOT
Dari gambar diatas dapat disimpulakan bahwa posisi titik koordinat berada pada kuadran 1 yaitu menggunakan Strategi Agresif dimana perusahaan memiliki kekuatan dan peluang besar. Jadi di harapkan pengusaha harus lebih meningkatkan usahanya sehingga dapat memanfaatkan peluang dengan maksimal dan bisa menambah kekuatan dari usahanya, jika pengusaha bisa lebih agresif maka bisa di pastikan usaha tersebut akan semakin berkembang sehingga mendapatkan keuntungan dengan maksimal.

\section{KESIMPULAN}

Berdasarkan hasil dari penelitian analisis strategi pengembangan usaha rumah garam prisma di Desa Sedayulawas Kecamatan Brondong Kabupaten Lamongan dapat disimpulkan bahwa

1. Cara pembuatan rumah garam prisma tergolong mudah sehingga petanipetani garam lain di Kabupaten
Lamongan yang belum menggunakan teknik rumah garam dapat dengan mudah menerapkannya. Produktivitas rumah garam prisma lebih unggul dari teknik pembuatan garam biasa, dimana produktivitas bisa naik 3-4 kali lipat.

2. Berdasarkan analisis finansial usaha rumah garam prisma ini sangat menguntungkan dan layak untuk dijalankan.

3. Berdasarkan perhitungan analisis SWOT atau kuadran SWOT, strategi pengembangan usaha rumah garam prisma di Desa Sedayulawas Kecamatan Brondong Kabupaten Lamongan berada pada kuadran 1 yaitu menggunakan Strategi agresif

\section{SARAN}

Berdasarkan hail penelitian maka peneliti dapat menyarankan :

1. Perusahaan memiliki kekuatan dan peluang besar sehingga pengusaha harus lebih 
meningkatkan usahanya dan lebih agresif sehingga tersebut akan semakin berkembang

2. Petani-petani garam di Kabupaten Lamongan harus menerapkan teknik rumah garam karena roduktivitas rumah garam prisma lebih unggul dari teknik pembuatan garam biasa, dimana produktivitas bisa naik 3-4 kali lipat

\section{DAFTAR PUSTAKA}

Ardiyato, Wahyu Nurdiyanto, 2017, Rumah Garam Prisma Inovasi Tambak Garam Tanpa Terpengaruh Cuaca, TimesIndonesia.co.id (https://www.google.com/amp/s/amp.ti mesindonesia.co.id/read/153176/20170 731/131534/rumah-garam-prismainovasi-tambak-garam-tanpa-cuaca/)

Arikunto, S. 2002. Metodologi Penelitian Suatu Pendekatan Proposal. Jakarta: PT. Rineka Cipta.

Arikunto, S. 2013, Prosedur Penelitian: Suatu Pendekatan Praktik. Jakarta: Rineka Cipta.

Aziz Hidayat, 2017, Strategi Pengelolaan Produksi Garam Di Kecamatan Arungkeke Kabupaten Jeneponto Provinsi Sulawesi Selatan, Skripsi. Sekolah Pascasarjana Institut Pertanian Bogor, Bogor.

Badan Riset Dan SDM Kelautan Dan Perikanan, 2018, Kementrian Kelautan Kembangkan Pembuatan Garam Sistem Tertutup. Dinas Perikanan Dan Kelautan, Jakarta.

Burhanuddin. 2001 Proceending Forum Pasar Garam Indonesia. Badan Riset Kelautan Dan Perikanan. Jakarta.

Desrosier (1998) dalam amalia (2007), (http://eprints.ung.ac.id/973/6/2012-254243631410065-bab218012013023120.pdf).
Effendi Usman., Astuti Retno., Melati Candra D., 2017, Strategi Pengembangan Usaha Cokelat Menggunakan Quantitative Strategic Planing Matrix (QSPM) dan Multi Attribute Utility Theory (MAUT), Jurnal Teknologi dan Manajemen Agrobisnis, Vol 6 nomer 1:31-40.

Erwadi, H.W. dan H.W. Syafri. 2003 Strategi Agribinis Kelautan Perikanan. Alqaprint Jatinagor, Bandung.

Indriantoro, Nur \& Bambang Supomo, 1999. $M=$ Metodologi Penelitian dan Bisnis, Yogyakarta: BPFE Yogyakarta.

Kementrian Kelautan Dan Perikanan, 2013, Pusat Penelitian dan Pengembangan Sumberdaya Laut dan Pesisir. Kementrian Kelatautan Dan Perikanan, Jakarta.

Kementrian Kelautan Dan Perikanan, 2018, Penuhi Kebutuhan Garam Konsumsi Dengan Produksi Dalam Negri. Kementrian Kelautan Dan Perikanan, Jakarta.

Lexy J. Moleong, Metodologi Penelitian Kualitatif. Bandung : PT Remaja.

Moleong. J Lexy. 2005 Metode Penelitian Kualitatif Bandung, PT Remaja Rosdakarya.

Tilawa Gauri Indi, 2018, Strategi Pengembangan Agrobisnis Ikan Pindang Layang Di Desa Brondong Kecamatan Brondong Kabupaten Lamongan, Skripsi. Fakultas Perikanan Universitas Islam Lamongan.

Widiarto, S.B., M. Hubeis \& K. Sumantadinata. 2013 Efektivitas Program Pemberdayaan Usaha Garam Rakyat di Desa Losarang Indramayu. Manajemen IKM. 8 (2): 144-154. 